\title{
EFFECT OF MICROWAVE TREATMENT ON THE IMPREGNABILITY AND MECHANICAL PROPERTIES OF Eucalyptus globulus WOOD
}

Eva Hermoso ${ }^{1}$, Abel Vega ${ }^{2, \text {, }}$

\begin{abstract}
Application of microwave energy to wood can increase permeability in order to improve the impregnation of treatments, particularly important in refractory species such as eucalyptus. However, microwave treatment can also affect the physical and mechanical properties of wood. This paper discusses the application of microwave treatments of different intensities to improve impregnability (uptake and retention) and examines the effects on the mechanical properties of eucalyptus wood (Eucalyptus globulus). Microwave treatments significantly improve uptake and retention of the protective agent, especially in the most severe treatment. In contrast, there was a clear decrease in mechanical properties (modulus of elasticity and bending, compression, tension and shear strength) as a function on the energy applied. The effect of microwaves on the properties of wood varies depending on moisture content at the time of treatment.
\end{abstract}

Keywords: Bending strength, compression strength, high frequency treating, modulus of elasticity, retention, tension strength, shear strength.

\section{INTRODUCTION}

The application of microwaves (MW) to wood has been widely studied (Oloyede and Groombridge 2000, Leiker and Aurich 2003, Hanson 2007, Torgovnikov and Vinden 2010) for drying (Antti 1999, Leiker and Adamska 2004, Resch 2006), increasing permeability (Mollekopf and Wagenfür 2002) or improving wood properties for pulping (Torgovnikov and Vinden 2009).

Microwaves consist of electromagnetic energy at frequencies between $300 \mathrm{MHz}$ and $300 \mathrm{GHz}$. MW energy absorption produces the random vibration of polarized molecules, leading to an increase in temperature. Although water molecules are significantly affected, unsurprisingly given their high dielectric permittivity, other polar molecules in wood (cellulose, hemicellulose and lignin) can also be affected (Hansson and Antii 2003). The heat generated is absorbed in different ways depending on the type cell affected (tracheids, fibers). Pressure causes fractures and the creation of micro-holes in thinwalled cells, increasing the permeability of the wood.

MW energy applied for wood modification needs to be in the range of 250 to $1200 \mathrm{MJm}^{-3}$, depending on the purpose. For example, MW processing to increase the uptake of water-based preservatives for some softwood species (Stika spruce, radiata pine) needs energy in the range of 250 to $400 \mathrm{MJm}^{-3}$ and this energy needs to be higher for highly refractory hardwood species (Torgovnikov and Vinden 2010). It is important to select MW energy that does not excessively damage the wood structure or significantly affect the mechanical properties, but still improves permeability. The energy required depends on the size of the piece and initial moisture content. 
The objective of this paper was to study the application of different energies based on MW treatments to Eucalyptus globulus heartwood (a refractory species) in order to improve permeability, while at the same time evaluating the influence on the mechanical properties.

\section{MATERIAL AND METHODS}

Heartwood samples of Eucalyptus globulus L. from the Northwest of Spain were obtained from commercial boards. The objective was the evaluation of the standard wood existing on the market, without previous selection by tree or log. A total of 350 samples $\left(20 \times 30 \times 350 \mathrm{~mm}^{3}\right)$ were prepared avoiding the presence of knots, cracks or other defects. The samples were divided into 7 groups of 50 specimens, one group corresponding to each MW treatment configuration. The initial moisture content of all the samples was over $30 \%$.

Four of the groups were conditioned to an approximate moisture content of $12 \%$ (dry sample groups D1, D2 and D3 for treatments 1, 2 and 3 respectively and a reference group/control, R), while the moisture content of the other three groups remained above $30 \%$ (green sample groups G1, G2 and G3 for the treatments 1, 2 and 3 respectively).

Table 1. MW energies (E) and initial moisture content (MC) conditions tested for their effects on permeability and mechanical properties of Eucalyptus globulus.

\begin{tabular}{cccc}
\hline Group & $\mathrm{n}$ & $\mathrm{E}\left(\mathrm{MJm}^{-3}\right)$ & $\mathrm{MC}(\%)$ \\
\hline R & 50 & None & $12 \%$ \\
\hline D1 & 50 & 290 & $12 \%$ \\
\hline D2 & 50 & 360 & $12 \%$ \\
\hline D3 & 50 & 430 & $>30 \%$ \\
\hline G1 & 50 & 290 & $>30 \%$ \\
\hline G2 & 50 & 360 & $>30 \%$ \\
\hline G3 & 50 & 430 & \\
\hline
\end{tabular}

Samples were treated in a laboratory MW measuring 400x280x240 $\mathrm{mm}^{3}$ (inner chamber), with a frequency of $2,45 \mathrm{GHz}$ and a magnetron with a power rating of $500 \mathrm{~W}$ and homogeneous distribution of energy within the chamber. A frequency of $2,45 \mathrm{GHz}$ is suitable for treating pieces with thicknesses up to $90 \mathrm{~mm}$ (Torgovnikov and Vinden 2009). Treatment times were defined based on the power supplied and the volume of the samples in order to reach the desired energies (Table 1).

Immediately after the treatment, the samples were weighed and their moisture content (using hygrometer TESTO 616) and temperature (T) measured. Subsequently, all samples were conditioned to achieve a moisture content of $12 \%$ in preparation for impregnation and mechanical tests.

\section{Evaluation of impregnability}

10 samples from each treatment (and control) were sealed at their ends with paraffin and treated in autoclave with $2 \%$ solution of water-soluble salts TANALITH E (vacuum conditions of 0,3 bar and pressure of 9 bar for 120 minutes).

After the treatment, samples were weighed and the differences between pre- and post-treatment were used to calculate uptake $(\%)$ and retention $\left(\mathrm{kgm}^{-3}\right)$ rates. Retention was calculated considering the concentration of active ingredients in the product $(2 \%)$. 


\section{Evaluation of mechanical properties}

Remaining 40 samples from each MW treatment were tested to evaluate the mechanical properties: modulus of elasticity parallel to the grain $\left(\mathrm{E}_{\mathrm{m}}\right)$, bending strength $\left(\mathrm{f}_{\mathrm{m}}\right)$, compression strength $\left(\mathrm{f}_{\mathrm{c}, 0}\right)$, tension strength $\left(f_{t, 0}\right)$ and shear strength $\left(f_{v}\right)$. Modulus of elasticity and bending strength tests were performed as defined in ISO 13061-4,2 and ISO 13061-3,2; respectively, using a universal testing machine, model ELIB-30, with a load capacity of $30 \mathrm{kN}$. Shear strength tests were made according to UNE 56543. Compression and tension strength tests were performed according to EN 408 (sample dimensions were modified to $10 \times 10 \times 150 \mathrm{~mm}^{3}$ for compression and tension tests according to the standard).

\section{Statistical analysis}

Differences between treatments were evaluated by classical analysis of variance ANOVA $(\alpha=0,05)$; using PASW Statistics software (version 18.0).

\section{RESULTS AND DISCUSSION}

\section{Moisture content, temperature and visual damages}

Table 2 shows the means of percentage of moisture content loss and of surface temperature increase following treatment. In dry samples $(12 \% \mathrm{MC})$ the maximum moisture content loss was observed at the maximum MW energy, with an average value of 2,12\%. In green samples, (initial moisture content above $30 \%$ ) the greatest drying effect was observed, with losses ranging from $4,74 \%$ in treatment 1 to $11,87 \%$ at the highest intensity.

Table 2. Moisture content loss and temperature increase.

\begin{tabular}{ccccc}
\hline $\mathrm{MC}(\%)$ & $\mathrm{n}$ & $\mathrm{E}\left(\mathrm{MJm}^{-3}\right)$ & $\mathrm{MC} \operatorname{loss}(\Delta \%)$ & T increase $\left(\Delta^{\circ} \mathrm{C}\right)$ \\
\hline 12 & 50 & 290 & $-1,64$ & 104,35 \\
\hline 12 & 50 & 360 & $-1,83$ & 122,38 \\
\hline 12 & 50 & 430 & $-2,12$ & 135,15 \\
\hline$>30$ & 50 & 290 & $-4,74$ & 16,12 \\
\hline$>30$ & 50 & 360 & $-7,04$ & 100,13 \\
\hline$>30$ & 50 & 430 & $-11,87$ & 106,12 \\
\hline
\end{tabular}

Temperature increases on the wood surface were higher in dry samples. This causes the thermal degradation of the wood during exposure to MW energy (Smith et al. 1996). The degradation occurs in wood heated above $100^{\circ} \mathrm{C}$, and can affect the chemical constituents of the cell wall or cause major structural damage (Saporiti 2006). Increasing energy seems to be associated with increasing splitting and cracks, particularly in the dry samples (Figure 1). 


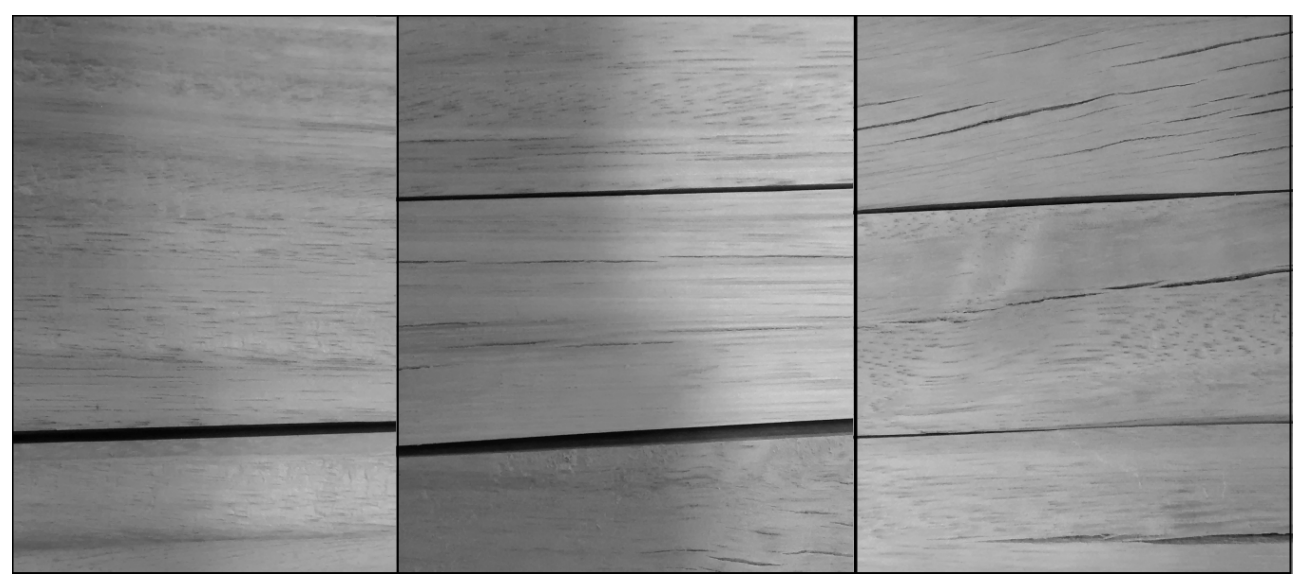

Figure 1. Surface appearance of MW treated eucalyptus wood. Left: $290 \mathrm{MJm}^{-3}$ (D1); Center: 360 $\mathrm{MJm}^{-3}(\mathrm{D} 2)$; Right: $430 \mathrm{MJm}^{-3}(\mathrm{D} 3)$.

\section{Uptake and retention}

The results for the 7 groups tested are shown in table 3 and figures 2-3. Both absorption and retention showed significant differences depending on the MW treatment applied. These differences tended to be greater when the treatment occurred in the green samples (G1, G2 and G3).

Table 3. Effect of microwave treatment on permeability of E. globulus as measured by uptake of a salt solution applied by pressure treatment.

\begin{tabular}{ccccc}
\hline Group & $\mathrm{n}$ & Uptake $\left(\mathrm{Lm}^{-3}\right)$ & Uptake $(\%)$ & Retention $\left(\mathrm{kgm}^{-3}\right)$ \\
\hline R & 10 & $55,9( \pm 15,1)^{(\mathrm{a})}$ & $6,4( \pm 2,0)^{(\mathrm{a})}$ & $1,7( \pm 0,3)^{(\mathrm{a})}$ \\
\hline D1 & 10 & $84,9( \pm 32,3)^{(\mathrm{b})}$ & $9,7( \pm 3,4)^{(\mathrm{a})}$ & $2,6( \pm 0,7)^{(\mathrm{a})(\mathrm{b})}$ \\
\hline D2 & 10 & $87,5( \pm 23,0)^{(\mathrm{b})}$ & $10,1( \pm 2,9)^{(\mathrm{a})(\mathrm{b})}$ & $2,6( \pm 0,5)^{(\mathrm{b})}$ \\
\hline D3 & 10 & $106,2( \pm 36,5)^{(\mathrm{b})}$ & $12,9( \pm 5,0)^{(\mathrm{b})}$ & $3,2( \pm 0,7)^{(\mathrm{b})}$ \\
\hline G1 & 10 & $111,4( \pm 47,1)^{(\mathrm{b})(\mathrm{c})}$ & $13,8( \pm 6,5)^{(\mathrm{b})(\mathrm{c})}$ & $3,1( \pm 0,9)^{(\mathrm{b})}$ \\
\hline G2 & 10 & $99,8( \pm 44,2)^{(\mathrm{b})}$ & $11,8( \pm 5,5)^{(\mathrm{b})}$ & $3,0( \pm 0,9)^{(\mathrm{b})}$ \\
\hline G3 & 10 & $139,0( \pm 31,5)^{(\mathrm{c})}$ & $17,1( \pm 4,3)^{(\mathrm{c})}$ & $4,2( \pm 0,6)^{(\mathrm{c})}$ \\
\hline
\end{tabular}

Values followed by the same letter do not differ significantly at $\alpha=0,05$ 


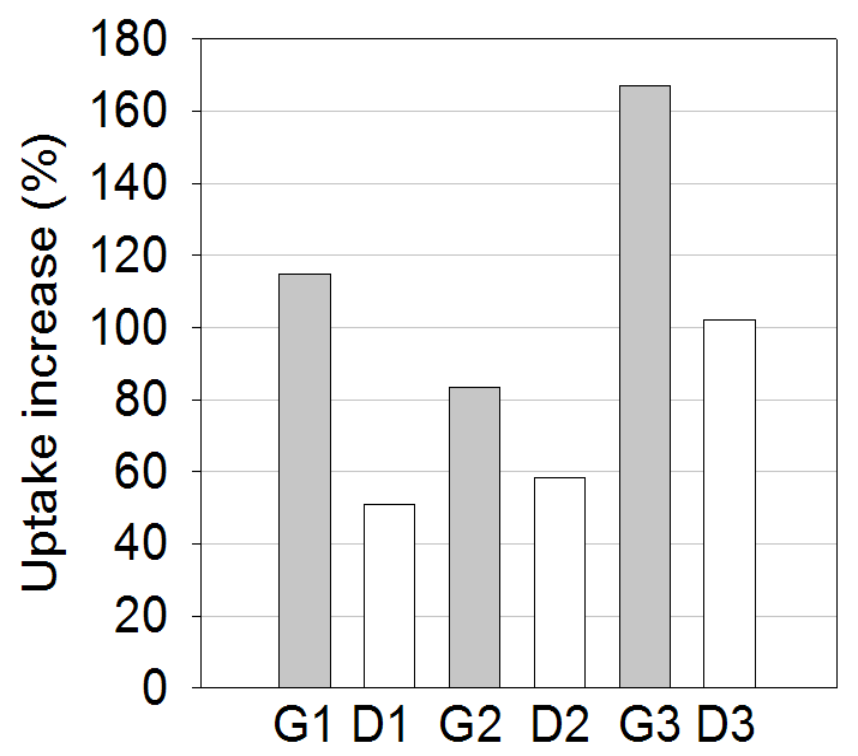

Figure 2. Effect of microwave treatment on permeability as determined by changes in solution

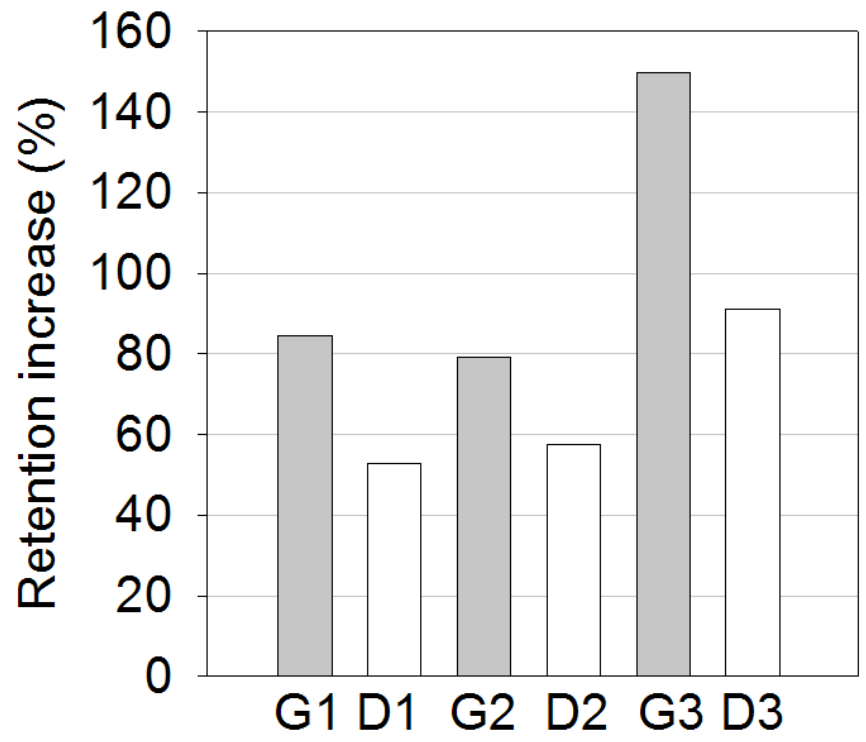

Figure 3. Effect of microwave treatment on permeability as determined by changes in solution retention during pressure treatment. 
Torgornikov and Vinden 2010, showed that energy ranges between 570 and $850 \mathrm{MJm}^{-3}$ were suitable for improving the impregnability of highly refractory species such as messmate (Eucalyptus obliqua), increasing uptake by a factor between 8 and 14. Uptake increases in the samples of this study were 2,7 times the reference values, though the energy applied was lower $\left(430 \mathrm{MJm}^{-3}\right)$. However, more intense treatments were not used because of concerns about degradation of the wood.

Treu et al. (2008), demonstrated that MW irradiation of spruce wood led to increased water uptake after vacuum and pressure impregnation. The authors proposed decreasing the exposure time to avoid cracking and cell wall degradation but using higher power at shorter intervals and multiple cycles. In contrast, Hansson and Antti (2003), proposed longer treatment times at a lower power. Further studies on the treatment configuration for Eucalyptus globulus wood need to be performed in the future to better define the optimum parameters to increase permeability with minimum effect on wood properties.

\section{Mechanical properties}

The results from the mechanical tests are shown in table 4. Modulus of elasticity $\left(\mathrm{E}_{\mathrm{m}}\right)$, bending strength $\left(f_{m}\right)$, compression strength $\left(f_{c, 0}\right)$, tension strength $\left(f_{t, 0}\right)$ and shear strength $\left(f_{v}\right)$ decrease as a function of the MW energy applied (Figure 4).

Table 4. Effect of microwave treatment on mechanical properties of Eucalyptus globulus treated at $12 \%$ or $>30 \%$ moisture content. Values represent means and standard deviation.

\begin{tabular}{cccccccc}
\hline Group & $\mathrm{n}$ & $\begin{array}{c}\mathrm{MC} \\
(\%)\end{array}$ & $\begin{array}{c}\mathrm{E}_{\mathrm{m}} \\
(\mathrm{MPa})\end{array}$ & $\begin{array}{c}\mathrm{f}_{\mathrm{m}} \\
(\mathrm{MPa})\end{array}$ & $\begin{array}{c}\mathrm{f}_{\mathrm{c}, 0} \\
(\mathrm{MPa})\end{array}$ & $\begin{array}{c}\mathrm{f}_{\mathrm{t}, 0} \\
(\mathrm{MPa})\end{array}$ & $\begin{array}{c}\mathrm{f}_{\mathrm{v}} \\
(\mathrm{MPa})\end{array}$ \\
\hline R & 40 & 12 & $\begin{array}{c}18293,1 \\
( \pm 1762,2)^{(\mathrm{a})}\end{array}$ & $\begin{array}{c}132,9 \\
( \pm 15,7)^{(\mathrm{a})}\end{array}$ & $\begin{array}{c}72,4 \\
( \pm 8,5)^{(\mathrm{b})}\end{array}$ & $\begin{array}{c}78,1 \\
( \pm 8,5)^{(\mathrm{a})}\end{array}$ & $\begin{array}{c}21,5 \\
( \pm 1,4)^{(\mathrm{a})}\end{array}$ \\
\hline D1 & 40 & 12 & $\begin{array}{c}18004,5 \\
( \pm 2813,5)^{(\mathrm{a})(\mathrm{b})}\end{array}$ & $\begin{array}{c}114,6 \\
( \pm 18,7)^{(\mathrm{b})}\end{array}$ & $\begin{array}{c}76,2 \\
( \pm 9,6)^{(\mathrm{a})}\end{array}$ & $\begin{array}{c}79,3 \\
( \pm 7,6)^{(\mathrm{a})}\end{array}$ & $\begin{array}{c}21,5 \\
( \pm 1,6)^{(\mathrm{a})}\end{array}$ \\
\hline D2 & 40 & 12 & $\begin{array}{c}17287,9 \\
( \pm 1919,6)^{(\mathrm{b})}\end{array}$ & $\begin{array}{c}112,8 \\
( \pm 12,3)^{(\mathrm{b})}\end{array}$ & $\begin{array}{c}73,1 \\
( \pm 10,3)^{(\mathrm{b})}\end{array}$ & $\begin{array}{c}77,6 \\
( \pm 8,2)^{(\mathrm{a})}\end{array}$ & $\begin{array}{c}21,0 \\
( \pm 2,0)^{(\mathrm{a})}\end{array}$ \\
\hline D3 & 40 & 12 & $\begin{array}{c}12260,5 \\
( \pm 1971,5)^{(\mathrm{c})}\end{array}$ & $\begin{array}{c}87,1 \\
( \pm 11,8)^{(\mathrm{c})}\end{array}$ & $\begin{array}{c}47,3 \\
( \pm 11,1)^{(\mathrm{c})}\end{array}$ & $\begin{array}{c}54,1 \\
( \pm 7,6)^{(\mathrm{b})}\end{array}$ & $\begin{array}{c}16,4 \\
( \pm 2,6)^{(\mathrm{b})}\end{array}$ \\
\hline G1 & 40 & $>30$ & $\begin{array}{c}18454,1 \\
( \pm 2077,7)^{(\mathrm{a})}\end{array}$ & $\begin{array}{c}131,3 \\
( \pm 20,5)^{(\mathrm{a})}\end{array}$ & $\begin{array}{c}71,8 \\
( \pm 10,5)^{(\mathrm{a})}\end{array}$ & $\begin{array}{c}74,5 \\
( \pm 6,0)^{(\mathrm{a})}\end{array}$ & $\begin{array}{c}21,1 \\
( \pm 1,3)^{(\mathrm{a})}\end{array}$ \\
\hline G2 & 40 & $>30$ & $\begin{array}{c}16768,4 \\
( \pm 2023,0)^{(\mathrm{b})}\end{array}$ & $\begin{array}{c}131,8 \\
( \pm 15,5)^{(\mathrm{a})}\end{array}$ & $\begin{array}{c}69,5 \\
( \pm 9,8)^{(\mathrm{a})}\end{array}$ & $\begin{array}{c}72,9 \\
( \pm 8,7)^{(\mathrm{a})}\end{array}$ & $\begin{array}{c}20,1 \\
( \pm 2,0)^{(\mathrm{a})}\end{array}$ \\
\hline G3 & 40 & $>30$ & $\begin{array}{c}14135,5 \\
( \pm 1923,1)^{(\mathrm{c})}\end{array}$ & $\begin{array}{c}107,8 \\
( \pm 15,0)^{(\mathrm{b})}\end{array}$ & $\begin{array}{c}51,0 \\
( \pm 9,7)^{(\mathrm{b})}\end{array}$ & $\begin{array}{c}56,3 \\
( \pm 7,8)^{(\mathrm{b})}\end{array}$ & $\begin{array}{c}19,9 \\
( \pm 2,4)^{(\mathrm{a})}\end{array}$ \\
\hline Van
\end{tabular}

Values within the same MC followed by the same letter do not differ significantly at $\alpha=0,05$. 


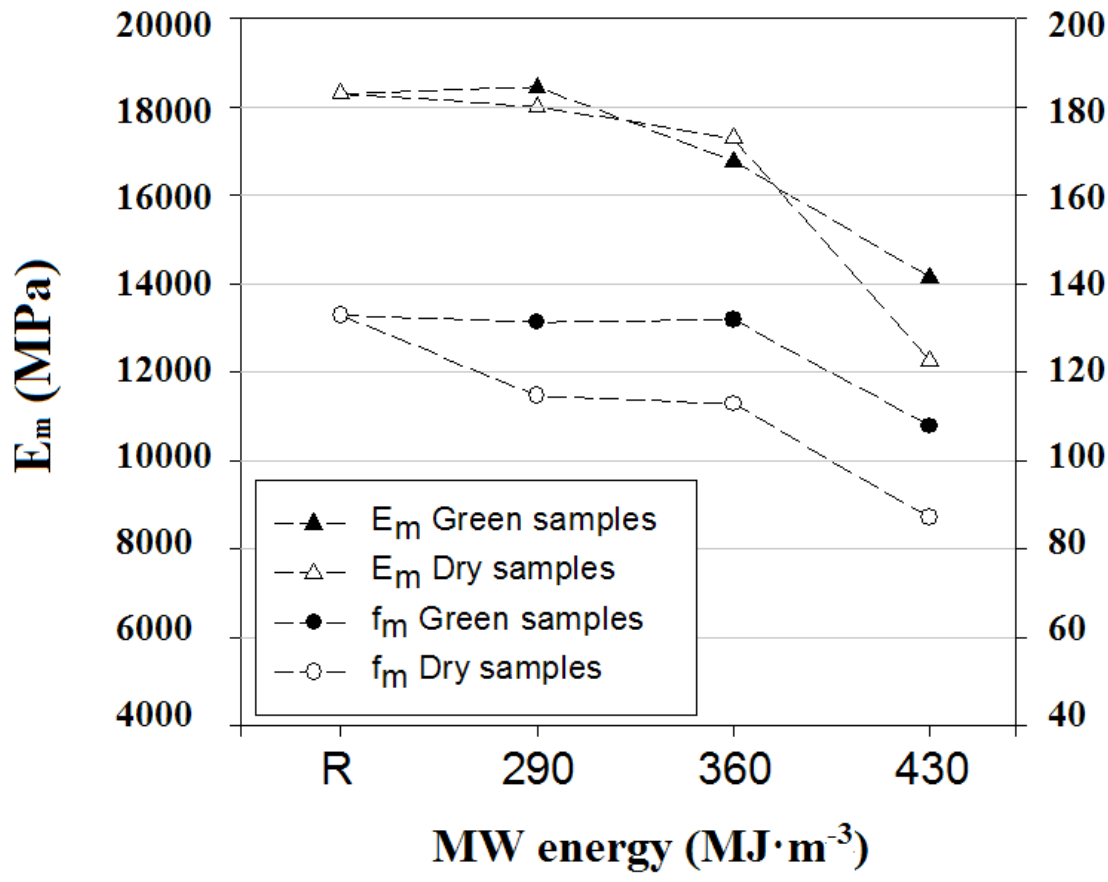

Figure 4. Relationships between MW energies, moisture content and mechanical properties (modulus of elasticity and bending strength) of Eucalyptus globulus.

MW energy supplied has significant influence on stiffness, and this effect was more pronounced in the dry samples. This tendency was similar with respect to bending strength. The MW treatment with the greatest influence on these two variables was the most severe, where the modulus of elasticity $\left(\mathrm{E}_{\mathrm{m}}\right)$ decreased by $33 \%$ and $23 \%$ compared to the reference (dry and green samples, respectively), while the bending strength $\left(\mathrm{f}_{\mathrm{m}}\right)$ decreased by $34 \%$ and $19 \%$ (dry and green samples respectively). The reduced effect on the green samples may be due to the fact that a substantial proportion of the energy applied to green samples was used to dry the wood before the conditions which cause chemical or structural damage were reached.

Compression, tensile and shear strength, with one exception, all showed significant changes for treatment 3 , in both green and dried samples, in terms of a significant decrease in all values, the exception being green sample shear strength. 
These results were similar to those reported by Torgovnikov and Vinden (2009), showing a decrease in both $\mathrm{E}_{\mathrm{m}}$ and $\mathrm{f}_{\mathrm{m}}$ of messmate (Eucalyptus obliqua) wood after applying microwave energy between 250 and $600 \mathrm{MJm}^{-3}$. The decrease in the values of these variables was significant in treatments above $300 \mathrm{MJm}^{-3}$, with decreases of $35 \%$ and $12 \%$ respectively when applying energy of $400 \mathrm{MJm}^{-3}$. Furthermore, Saporiti (2006) has indicated a notable decrease in compressive strength in oak (Querqus pyrenaica) when applying three MW treatments similar to those of the present work (550 W and 2,45 $\mathrm{GHz})$.

\section{CONCLUSIONS}

Microwave treatment $\left(430 \mathrm{MJm}^{-3}\right)$ on Eucalyptus globulus wood before the conventional impregnation process results in a 2,28-fold increase in uptake and a 2,50-fold increase in retention compared to the values of the reference samples.

Wood stiffness and strength decreased significantly, especially for the most severe treatment (430 $\left.\mathrm{MJm}^{-3}\right)$. The effect of MW treatment on the properties of wood is variable, depending on the initial moisture content, being lower in moisture contents above $30 \%$.

In view of the results, the range of energy that provides a balance between improving impregnability without affecting other properties of the material is between 360 and $430 \mathrm{MJm}^{-3}$.

These conclusions refer to studies of samples of small dimensions free of defects of Eucalyptus globulus heartwood. Future new works evaluating structural size wood are therefore necessary.

\section{ACKNOWLEDGEMENTS}

The authors would like to thank INIA (Instituto Nacional de Investigación y Tecnología Agraria y Alimentaria) for funding of the research project "Hi Frequency Impregnation of Wood (Hi Fretech)", through the Woodwisdom-Net Research Programme. Also they want to thank Roonie Lendrum for her work on checking and correction of English text. 


\section{REFERENCES}

Antti, L. 1999. Heating and drying Wood using microwave power. PhD Thesis, Skelleftea, Sweden.

EN 408. 2011. Timber structures. Structural timber and glued laminated timber. Determination of some physical and mechanical properties. Spanish Association for Standardization and Certification (AENOR).

Hanson, L. 2007. Microwave Treatment of Wood. Doctoral Thesis. Luleå University of Technology, Sweden.

Hanson, L.; Antii, A. 2003. The effect of microwave drying on Norway spruce wood strength: a comparison with conventional drying. Journal of Materials Processing Technology 141(1): 41-50.

International Organization for Standardization. ISO. 2013. Physical and mechanical properties of wood. Test methods for small clear specimen-Part 4: Determination of modulus of elasticity in static bending. ISO/DIS 13061-4.2.

International Organization for Standardization. ISO. 2013. Physical and mechanical properties of wood. Test methods for small clear specimen-Part 3: Determination of ultimate strength in static bending. ISO/DIS 13061-3.2.

Leiker, M.; Adamska, M.A. 2004. Energy efficiency and drying rates during vacuum microwave drying of wood. Holz als Roh-und Werkstoff 62: 203-208.

Leiker, M.; Aurich, K. 2003. Sorption behavior of microwave dried wood. $8^{\text {th }}$ international IUFRO wood drying conference, Brasov, Romania, 237-240.

Mollekopf, N.; Wagenführ, A. 2002. Neues verfahren verbessert schnittholztrocknung. HolzZentral-Blatt 137: 1627.

Oloyede, A.; Groombridge, P. 2000. The influence of microwave heating on the mechanical properties of wood. Journal of Materials Processing Technology 100: 67-73.

Resch, H. 2006. High-frequency electric current for drying of wood-Historical perspectives. Maderas-Ciencia y tecnología 8(2): 67-82.

Saporiti, J. 2006. Effect of microwave treatment on oak compression strength. Silva Lusitana 14(1): 51-58.

Smith, W.B.; Schneider, P.F.; Resch, H. 1996. Rapid fixation of CCA wood preservative with electromagnetic energy. Forest Products Journal 46 (7-8): 47-51.

Torgovnikov, G.; Vinden, P. 2009. High-intensity microwave wood modification for increasing permeability. Forest Products Journal 59(4): 84-92.

Torgovnikov, G.; Vinden, P. 2010. Microwave wood modification technology and its applications. Forest Products Journal 60(2): 173-182.

Treu, A.; Rieche, H.; Militz, H. 2008. Spruce and pine heartwood treatment by means of microwave radiation. The International Research Group on Wood Protection, $39^{\text {th }}$ Annual Meeting, Istanbul, Turkey, IRG/WP 08-40411. 
UNE 56543. 1988. Características físico-mecánicas de la madera. Determinación del esfuerzo cortante. Spanish Association for Standardization and Certification (AENOR). 